\title{
Age estimation in giant otters (Pteronura brasiliensis) (CARnivora: Mustelidae) USING GROWTH LAYER GROUPS IN CANINE TEETH
}

\author{
Gabriel da Cruz de Oliveira, José Fernando Marques Barcellos² and Fernando César Weber Rosas ${ }^{3}$
}

\begin{abstract}
The canines of six giant otters Pteronura brasiliensis ( 5 males and 1 female) from the zoological collection of the National Institute of Amazonian Research (INPA) were analyzed for age estimation. Of these, two were from known-age

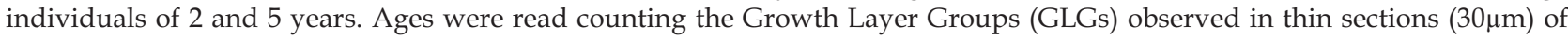
decalcified teeth. GLGs were present in the dentine but were not conspicuous; age estimates were only reliable when counted in the cementum. Periodicity of GLGs and age estimates were calibrated with the known-age individuals. Results revealed an annual deposition pattern of GLGs in the cementum of giant otter canines, and no apparent differences were found in the GLG patterns observed between males and females, or between captive and free-ranging individuals. The youngest and oldest giant otters analyzed were 2 and 20 years old, respectively. These results suggest that the longevity of captive giant otters is around 20 years. The age determination technique applied here proved to be useful for age estimation in giant otters and can contribute as a powerful tool for future studies on the population dynamics of P. brasiliensis, which is currently classified as endangered.

Resumo: Dentes caninos de cinco machos e uma fêmea de ariranha depositados na Coleção de Mamíferos do Instituto Nacional de Pesquisas da Amazônia foram analisados para estimativa de idade nesta espécie. Desses, dois eram animais de idade conhecida, com idades de 2 e 5 anos. As idades foram lidas contando-se o número de camadas de crescimento (GLGs) observadas em secções finas $(30 \mu \mathrm{m})$ de dentes. Embora se observem GLGs na dentina, essas não são conspícuas. Estimativas confiáveis de idade puderam ser feitas somente no cimento. O padrão de deposição dos GLGs e as idades estimadas no cimento dos caninos de ariranha foram calibrados com os animais de idade conhecida e os resultados revelaram um padrão de deposição de um GLG por ano. Não foram encontradas diferenças no padrão de deposição dos GLGs entre machos e fêmeas e tampouco entre animais cativos e de vida livre. A mais jovem e a mais velha das ariranhas analisadas nesse estudo tinham 2 e 20 anos, respectivamente. Esses resultados sugerem que a longevidade de ariranhas cativas está próxima dos 20 anos de vida. A técnica de determinação de idade aqui utilizada revelou ser útil para estimativa de idade em ariranhas e pode contribuir como uma valiosa ferramenta para futuros estudos de dinâmica populacional dessa espécie ameaçada de extinção.
\end{abstract}

KEYwonds: Teeth, age, growth layers, Pteronura brasiliensis, giant otter.

\section{Introduction}

The giant otter (Pteronura brasiliensis) is currently classified by The World Conservation Union as an "endangered species" (IUCN, 2006). However, virtually nothing is known about the population dynamics of this species and its longevity is still controversial in the literature. According to Staib (2005), the longevity of free-ranging giant otters is 11 years, while for captive animals the reported longevity is 20 years ( $F$. Brandstätter, pers. comm.).

Age composition is a vital parameter to assess the dynamics of any mammalian population (Scheffer \& Myrick, 1980), especially when dealing with threatened species. Growth Layer Groups (GLGs) observed in the dentine and cementum of mammalian teeth are widely used to estimate age in odontocete cetaceans (Perrin \& Myrick, 1980; Hohn et al., 1989). According to Klevezal (1996), the methods used to estimate age in mammals also include counting GLGs in the dentine and cementum of teeth. In carnivores, however, counting cementum layers is the most widely used method for age determination (Klevezal, 1996). Cementum layers were used to estimate age in river otters (Lontra canadensis) (Tabor \& Wight (1977), Eurasian otters (Lutra lutra) (Heggberget, 1984), and sea otters (Enhydra lutris) (Bodkin et al., 1997). According to Bodkin et al. (1997), variation in the GLGs deposited in the cementum occurs among and within species and may be caused by physiological (reproduction, estivation or nutrition) or environmental (temperature or daylight) factors. Therefore, the periodicity of cementum layers in giant otter teeth has to be tested and validated with knownage individuals.

According to Sykes-Gatz (2005), field biologists and institutions that hold giant otters in captivity are in need of accurate information regarding the age of sexual maturity, body weight/length relationships and growth curves, which can only be obtained after establishing a reliable method for age determination. Therefore, the main objective of this study was to test the age estimation technique using thin teeth sections from giant otters in order to verify its efficiency in this species.

\section{Material and Methods}

One upper canine tooth (Figure 1) was extracted from each of the five giant otter skulls deposited in the Mammal Collection of the National Institute of

\footnotetext{
${ }^{1}$ Universidade Federal do Amazonas - UFAM, Manaus, AM, Brazil.

${ }^{2}$ Universidade Federal do Amazonas - UFAM, Departamento de Morfologia - ICB, Laboratório de Histologia, Manaus, AM, Brazil.

${ }^{3}$ Instituto Nacional de Pesquisas da Amazônia - INPA, Laboratório de Mamíferos Aquáticos, Caixa Postal 478, Manaus, AM, 69011-970, Brazil.

* Corresponding author, e-mail: frosas@inpa.gov.br
} 
Amazonian Research (INPA). These five individuals were all captive males that had been kept in the INPA facilities up to their deaths (Table 1). One of the captive male otters (named Ticuna) was donated to INPA by the Cousteau Society team in 1982, when it was already an adult animal. This otter died 10 years later, in August 1992 (Table 1). The other captive animals were wild-caught otters by riverine people, who capture otter pups to sell as pets to tourists in the Amazon region. These otters were confiscated by IBAMA, the Brazilian Institute of the Environment and Natural Resources and taken to the INPA facilities to be raised. Their age when they arrived in captivity (based on size and weight), the time spent in captivity, their total length at death, and the estimated age (counting the GLGs in the cementum) are presented in Table 1. Additionally, one upper canine tooth was analyzed from a free-ranging female giant otter (see Table 1), which was found dead in Balbina hydroelectric lake in February 2002 (Rosas and de Mattos, 2003).

Bodkin et al. (1997) consider a known-age sea otter as being an individual less than one year old based only on its weight. We used a similar criterion to define known-age giant otters in this study. However, we took into account not only the weight, but also the size of the otters when they arrived at INPA. Only otters estimated to be $\leq 6$ months old were considered to be of known age.

All the teeth analyzed in this study were kept dry and maintained at air temperature until they were prepared for age estimation. The age estimation technique applied followed the method described by Hohn et al. (1989) and Rosas et al. (2003), with some modifications as follows.

\section{Decalcification and sectioning}

After the extraction, all external and internal pulp cavity tissues were removed by boiling the teeth. The most external lateral portions of the teeth were then removed using a diamond saw (Isomet ${ }^{\hat{a}}$ ) in order to allow for an easier and better decalcification process. After that, the teeth were left in a $10 \%$ formaldehyde solution for 24 hours and subsequently decalcified in $\mathrm{RDO}^{\circledR}$, a commercial decalcifying agent.

While in RDO, the teeth were periodically monitored in order to avoid overdecalcification, which precludes reliable GLG countings. Insufficient decalcification time, on the other hand, will damage the microtome blades and prevent acquiring intact sections.

The decalcified teeth were then sectioned longitudinally using a freezing microtome following the labial-lingual plane. Section thickness was adjusted to $30 \mu \mathrm{m}$ and only central or close-to-center sections, which presented at least $50 \%$ of the pulp cavity, were selected for age estimation.

\section{Staining}

The thin sections were left in Harris' hematoxilin for 3 to 5 minutes and then washed in running water for approximately 5 minutes to remove the excess hematoxilin, as recommended by Rosas et al. (2003). Afterwards, they were put in a $1 \%$ sodium borate solution to increase the contrast between layers and then washed in running water for 10 minutes, according to Molina and Oporto (1993).

\section{Slide mounting and growth layer readings}

The stained sections were placed into a 1:1 mixture of glycerin and distilled water for 5-10 minutes and then transferred to $100 \%$ glycerin for over 5 hours. The sections were then mounted between microscope slides and coverslips, and sealed with Entellan ${ }^{\circledR}$.

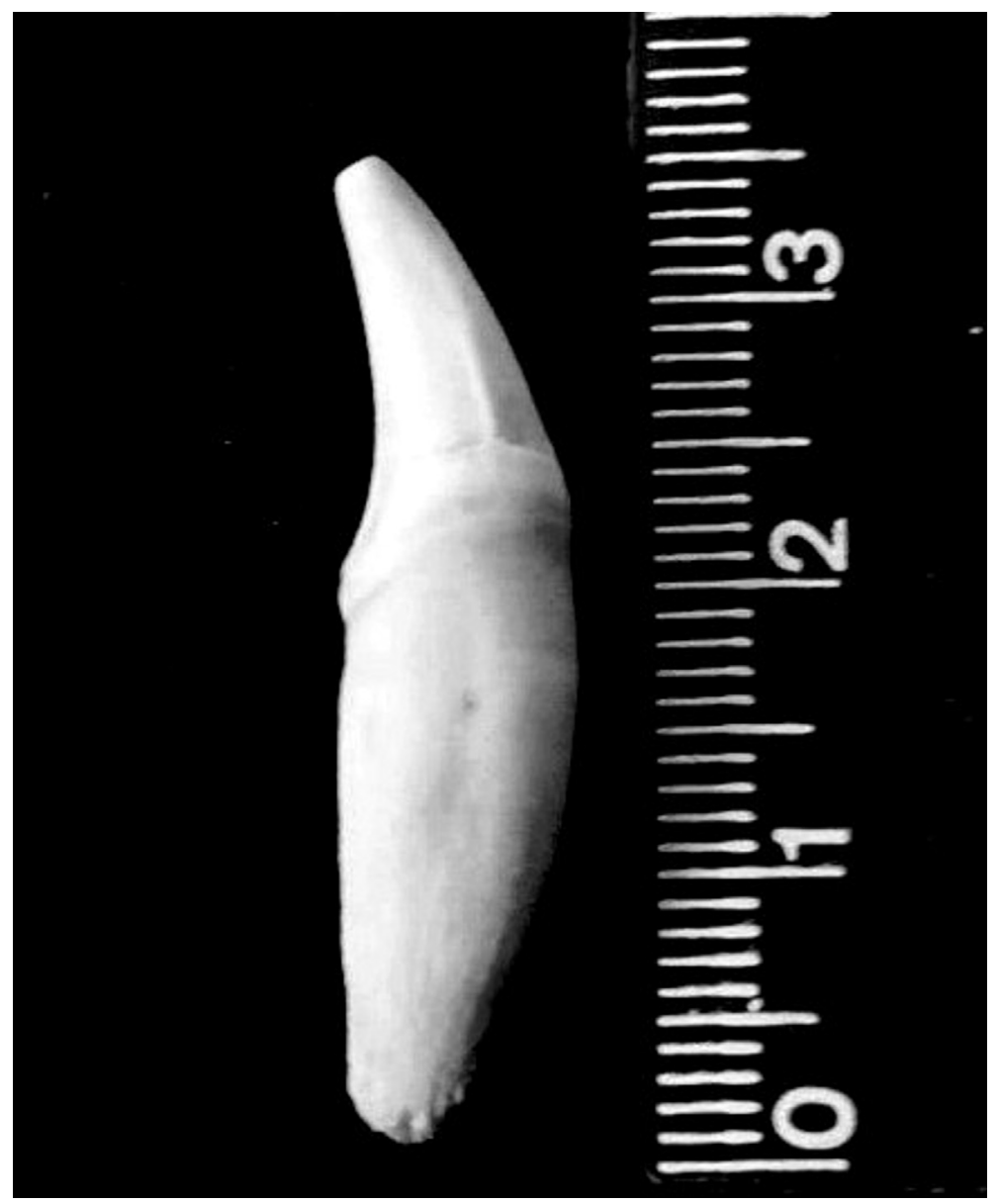

Figure 1. Upper canine tooth of giant otter (Pteronura brasiliensis). The scale is in centimeters. 
Table 1. Characteristics of the giant otters used in this study.

\begin{tabular}{lclcccc}
\hline \hline $\begin{array}{l}\text { ANIMAL } \\
\text { IDENTIFICATION }\end{array}$ & SEX & ORIGIN & $\begin{array}{c}\text { ESTIMATED AGE } \\
\text { WHEN ARRIVED IN } \\
\text { CAPTIVITY } \\
\text { (YEARS) }\end{array}$ & $\begin{array}{c}\text { TOTAL LENGTH } \\
\text { (IN cm) AT DEATH }\end{array}$ & $\begin{array}{c}\text { TIME IN } \\
\text { CAPTIVITY } \\
\text { (YEARS) }\end{array}$ & $\begin{array}{c}\text { ESTIMATED AGE } \\
\text { FROM GLGs } \\
\text { (YEARS) }\end{array}$ \\
\hline \hline Tícuna & $\mathrm{M}$ & Wild-caught & Adult (age unknown) & 155 & 10 & 20 \\
Kiwá & $\mathrm{M}$ & Wild-caught & $0.4^{*}$ & 157 & 5 & 5 \\
\hline \hline Sammy & $\mathrm{M}$ & Wild-caught & $0.5^{*}$ & 160 & 1.5 & 2 \\
Frank & $\mathrm{M}$ & Wild-caught & $? ?$ & 163 & 0.6 & 2 \\
\hline \hline Kiwi & $\mathrm{M}$ & Wild-caught & $? ?$ & 149 & 3 & 6 \\
Balbina \#1 & $\mathrm{F}$ & Found dead in the wild & --- & 150 & --- & 2 \\
\hline \hline
\end{tabular}

* Those otters which arrived at INPA with ages equal to or less than 0.5 year old were considered as known-age individuals.

Both the dentine and cementum of the giant otter teeth sections were observed for GLGs under a transmitted light microscope. However, it was only possible to determine a reliable age in the cementum. Age readings were carried out counting GLGs following the methodology described by Hohn et al. (1989). At least five readings were performed on each tooth section with a minimum interval of 3 days between readings. Age was estimated without access to biometric and biological data, thereby avoiding reader bias. Assuming that reading skill increases with time (Pinedo and Hohn, 2000), the estimated age was taken as the last reading. Age estimations were calibrated using deposition rates in teeth from the known-age individuals, allowing the identification of the periodicity of GLG deposition in giant otter teeth.

\section{Results}

Decalcification time of giant otter teeth varied from 13 hours for younger individuals up to a maximum of 23 hours for older adults, with a mean decalcification time of 17.5 hours. No age estimates could be carried out in the dentine due to a lack of conspicuousness of GLGs in this part of the teeth. However, the GLGs were readily observed in the cementum. Two major types of layers were identified: one thick unstained layer followed by one thin stained layer (Fig. 2). There was no difference between the GLG deposition observed in captive giant otters and the free-ranging individual analyzed. Nor were there differences observed between the GLG patterns in males when compared with the pattern presented by the female analyzed. The results revealed that age estimates corroborate the real ages of the known-age individuals. Nevertheless, due to the ramified layers sometimes observed in the giant otters ${ }^{\prime}$ teeth, it is important to follow the GLGs throughout the tooth root in order to avoid counting these ramified layers as two different annual layers. The agreement between the ages estimated by GLG counting and those of known-age animals, allowed us to assume that GLGs in the cementum of giant otter teeth follow an annual deposition. The youngest and oldest individuals in our sample were 2 and 20 years old, respectively (Figures $2 a$ and $2 c$ ). Worn, missing and broken teeth were observed in the 20 year-old giant otter, suggesting that this is an advanced age for P. brasiliensis.

\section{Discussion}

According to Heggberget (1984), the possibilities of ageing European otters (Lutra lutra) from their external characteristics are very limited because of their rapid growth. This is also true for the giant otter, as observations of captive $P$. brasiliensis show that one-year old animals are very difficult to distinguish from older individuals based on their size (F. Rosas, pers. obs.). According to Klevezal (1996), counting cementum layers is the standard when ageing carnivores, and this was the methodology used by Tabor and Wight (1977), Heggberget (1984) and Bodkin et al. (1997) to estimate ages in river otters, Eurasian otters and sea otters, respectively. Although the former authors do not mention anything about dentine layers in the otter species they work with, the reason for not using them is probably due to the lack of conspicuousness of the dentine layers, as observed here for giant otters.

Different methods have been used to prepare otters' teeth for age estimation, and all of them used thin sections, varying from 14 to $30 \mu \mathrm{m}$, which were decalcified and stained in buffered formic acid, nitric acid and in hydrochloric acid, and stained in Papanicolau Hematoxylin Stain Solution or Giemsa solution (Tabor and Wight, 1977; Heggberget, 1984; Bodkin et al., 1997). The methodology applied in the present study with giant otters followed the method largely used for odontocete cetaceans (Hohn et al., 1989), which also proved to be useful for giant otter age estimates in the cementum of canine teeth. However, we use Harris' hematoxylin, as suggested by Rosas et al. (2003), instead of Mayer's hematoxylin as recommended by Hohn et al. (1989). Harris' hematoxylin is much more efficient in staining 
thin sections, reducing the time of staining from 20-30 minutes when using Mayer's hematoxylin, to 3-6 minutes when using Harris' hematoxylin. Additionally, Harris' hematoxylin sections last longer when compared to Mayer's hematoxylin sections, which usually become faded a few months after preparation.
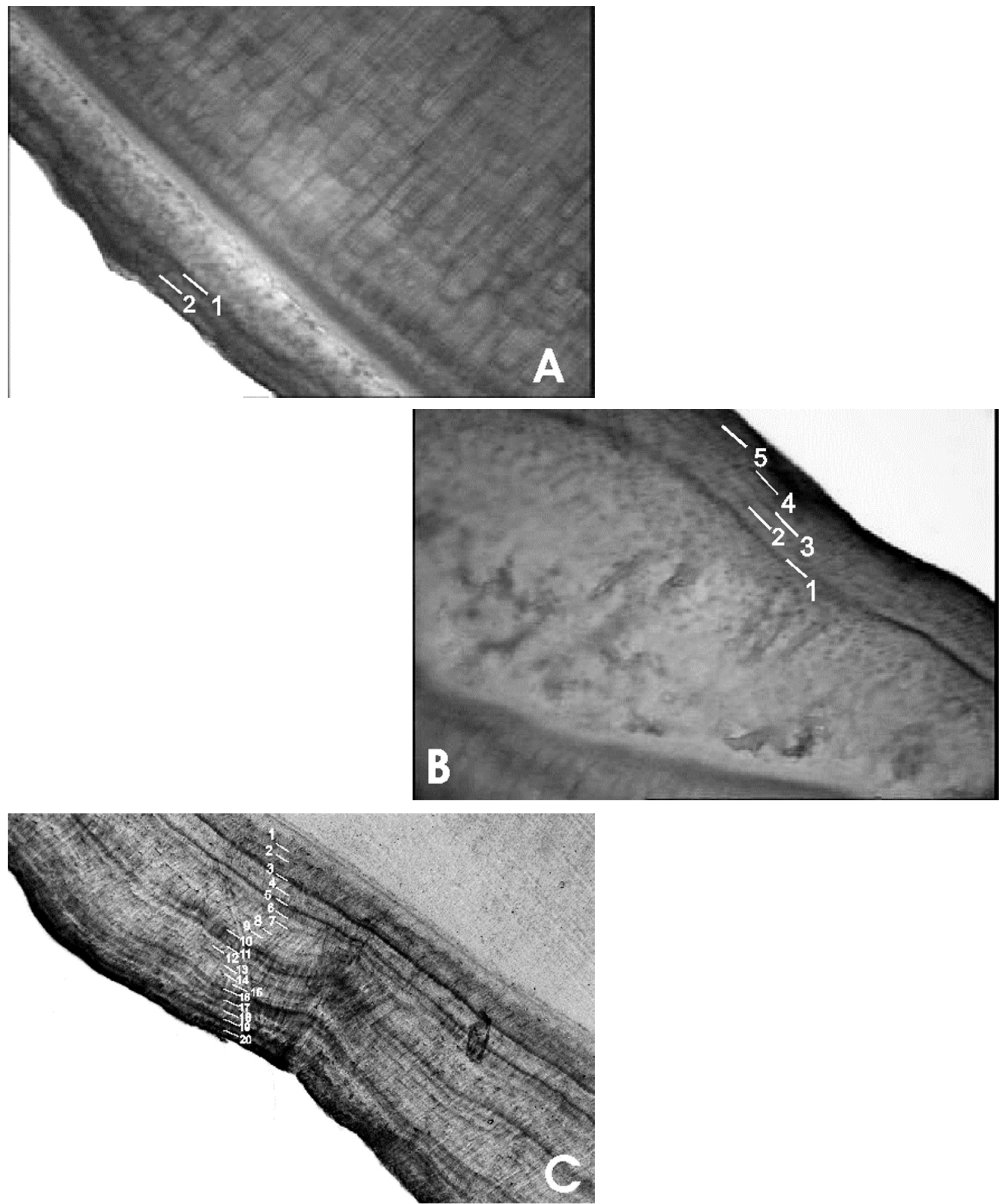

Figure 2. Tooth sections of giant otters showing the growth layer groups in the cementum. A known-age otter of two years of age (A), a known-age otter of five years of age (B), and a twenty year-old otter (C). 
The validation of age estimated by counting GLGs in teeth is of primary importance, as the ability to accurately estimate age is fundamental to study the age structure in populations, as well as age-specific measures of reproduction, growth or survival (Bodkin et al., 1997). Despite not having any known-age animals in their samples, the annual periodicity of the cementum layers was determined by Tabor and Wight (1977) by analyzing the ovary scars of river otters (Lontra canadensis), while Heggberget (1984) analyzed skull development in the European otter (Lutra lutra). However, the best validation of age estimates can be obtained when the sample contains known-age specimens, as presented by Bodkin et al. (1997) for the sea otter (Enhydra lutris), and in this study for giant otters (Pteronura brasiliensis).

The complexity and difficulties in estimating age in otters' cementum layers were presented by Bodkin et al. (1997), who analyzed the accuracy of age estimations between three independent readers and compared their age estimates with the age of known-age sea otters. According to those authors, despite the fact that the differences were not very evident when grouping the otters in age classes, they may contain large errors when estimating the age of individual sea otters. However, according to Pinedo \& Hohn (2000), estimated age accuracy tends to increase with time, as readers' skills increase with experience. The difficulties observed by Bodkin et al. (1997) may also be due to the fact that those authors used premolar sea otter teeth, while other age estimate studies in otters, including the present one, used the canines, which in carnivores are conical (Fig. 1) and bigger than the premolars, making age estimates easier.

The worn canine teeth, which can usually cause problems when estimating age in the dentine (Rosas et al., 2003), did not become a problem in this study as age estimates were performed in the cementum layers, and normally cementum is less subjected to resorption (Klevezal, 1996).

According to Brandstätter (2005), the oldest giant otter in captivity died at the age of 17 years, but its twin brother was still alive in 2005. Recent information obtained in May 2008 revealed that this animal is still alive and is 20 years old now (F. Brandstätter, pers. comm.), which is exactly the age of the oldest giant otter analyzed in the present study. Considering the worn teeth observed in that individual, it is reasonable to assume that this is an advanced age for giant otters, which is probably very close to the longevity of the species. Nonetheless, for most species, longevity of captive animals is not necessarily representative of the longevity of free-ranging individuals. This seems to be the case of giant otters, for which the longevity of freeranging animals is estimated to be around 11 years based on photo-identified otters (Staib, 2005).

Although the results presented here were based on a small number of animals, they do show that the pattern of GLGs observed in giant otter teeth is valuable for age estimation, as described for other species of otters (Tabor and Wight, 1977; Heggberget, 1984; Bodkin et al., 1997). Therefore, by using this method it is possible to relate features of the giant otter life cycle to an absolute time scale, thus greatly increasing their importance in understanding the population dynamics of the species.

According to the results obtained, age estimates in the dentine of giant otter teeth using the thin section method here applied are not recommended due to the lack of definition of GLGs in this structure. However, GLGs are very conspicuous and deposited on an annual basis in the cementum of giant otter canines as shown by known-age animals, providing accuracy in determining the absolute age in this species. According to Klevezal (1996), absolute age can also provide valuable information to estimate an individual's growth rate, and specific characteristics of reproduction and feeding. In addition, future age estimates from giant otter teeth deposited in museums and zoological collections will provide the establishment of growth curves for the species, as well as to determine with a higher degree of precision the age of sexual maturity in $P$. brasiliensis, which still needs to be defined.

\section{Acknowledgements}

We thank Kesä K. Lehti and Nélio Barros who kindly revised the English version of the manuscript. Dr. Aleta Hohn and an anonymous referee provided critical and insightful comments on the manuscript. We also thank Ingrid Karoline Albuquerque Ferreira who helped us with the teeth photographs. This work was partially funded by Conselho Nacional de Desenvolvimento Científico e Tecnológico (CNPq) by means of a grant to Gabriel da Cruz de Oliveira ("Programa de Iniciação Científica/UFAM/INPA").

\section{References}

Bodkin, J.L.; Ames, J.A.; Jameson, R.J.; Johnson, A.M. And Matson, G.M. (1997) Estimating age of sea otters with cementum layers in the first premolar. Journal of Wildlife Management 61 (3): 967-973.

BRANDSTÄTter, F. (2005) Maximum age of giant otters in captivity. Friends of the Giant Otter 12: 5.

Duplaix, N. (1980) Observations on the ecology and behaviour of the giant otter Pteronura brasiliensis in Suriname. Revue Ecologique (Terre Vie) 34: 495-620.

Heggberget, T.M. (1984) Age determination in the European otter Lutra lutra. Zeitschrift für Säugetierkunde 49: 299-305.

Hohn, A.A., Scott, M.D., Wells, R.S., Sweeney, J.C. And IRvine, A.B. (1989) Growth layers in teeth from known-age, free-ranging bottlenose dolphins. Marine Mammal Science 5(4): 315-342. 
IUCN (2006) 2006 IUCN Red List of Threatened Species. <www.iucnredlist.org>. Downloaded on 17 April 2007.

Klevezal, G.A. (1996) Recording structures of mammals. Determination of Age and Reconstruction of Life History. A.A. Balkema Publishers, Rotterdam, The Netherlands, 274 pp.

Molina, D.M. AND Oporto, J.A. (1993) Comparative study of dentine staining techniques to estimate age in the Chilean dolphin, Cephalorhynchus eutropia (Gray, 1846). Aquatic Mammals 19(1): 45-48.

Perrin, W.F. AND Myrick, A.C. (Eds) (1980) Age Determination of Toothed Whales end Sirenians. Reports of the International Whaling Commission (special issue 3). Cambridge, U.K., 229 pp.

Pinedo, M.C. and Hohn, A.A. (2000) Growth layer patterns in teeth from the franciscana, Pontoporia blainvillei: Developing a model for precision in age estimation. Marine Mammal Science 16(1): 1-27.

Rosas, F.C.W., Barreto, A.S. ANd Monteiro Filho, E.L.A. (2003) Age and growth of Sotalia guianensis (Cetacea, Delphinidae) on the coast of Paraná State, southern Brazil. Fishery Bulletin 101(2): 377-383

Rosas, F.C.W. and de Mattos, G.E. (2003) Natural deaths of giant otters (Pteronura brasiliensis) in Balbina hydroelectric lake, Amazonas, Brazil. IUCN Otter Specialist Group Bulletin 20(2): 62-64.

SCHEFfer, V.B. AND Mrrick, A.C. (1980) A review of studies to 1970 of growth layers in the teeth of marine mammals. Pages 51-63 in Perrin, W.F. ANd Myrick, A.C. (Eds) Age Determination of Toothed Whales and Sirenians. Reports of the International Whaling Commission (special issue 3). Cambridge, U.K.

StAIB, E. (2005) Eco-etologia del lobo de río (Pteronura brasiliensis) en el sureste del Perú. Sociedad Zoologica de Francfort Peru. Lima, Peru, $195 \mathrm{pp}$

SYKes-GatZ, S. (2005) International Giant Otter Studbook. Zoologischer Garten Dortmund, Dortmund, Germany, 120pp.

Tabor, J.E. AND Wight, H.M. (1977) Population status of river otter in Western Oregon. Journal of Wildlife Management 41(4): 692-699. 